\title{
COMMENTARY/
}

\section{WHEN PAST IS PROLOGUE}

\author{
by Bernard Dixon
}

$\mathrm{T}$ his is a story of two anniversaries, one a good deal more meritorious than the other, and a nice piece of work by Monsanto which puts both into perspective.

First, peer back 50 years to the paper by George Beadle and Edward Tatum in the Proceedings of the National Academy of Sciences $(27: 499,1941)$. This not only revolutionised genetics, by demonstrating the advantages of Neurospora crassa as research material. It also set the stage for molecular biology, by establishing that the action of particular enzymes could be atuributed to specific genes. When Beadle and Tatum irradiated spores of $N$. crassa, which normally grows on glucose, salts, and biotin, they found one mutant that grew only with the amine in the medium, and another that required pyridoxine instead. Irradiation had knocked out two different genes in the two organisms. Hence the "one geneone enzyme" concept, which in modern parlance means that every gene determines one protein or part of a protein. The pure molecular biology of Watson and Crick, and the applied genetic engineering of Cohen and Boyer, have both stemmed from this key concept.

The second anniversary goes back a mere 20 years, to the initial publication of Sir Macfarlane Burnet's Genes, Dreams and Realities, in the U.K. in 1971. Although penned by the Australian immunologist who shared the 1961 Nobel Prize with Peter Medawar for the discovery of acquired immunological tolerance, this was a gloomy commentary on the future of medical science and on the possible practical value of DNA research. Not only did Burnet remind readers that "there has been no human benefit whatever from all that has been learned of molecular biology." He also indicated that such rewards were likely to be meagre in future too.

Molecular biology was simply "the fashionable science, the one in which reputations are made, whose successes are applauded by presidents and royalty and from which the public, guided mainly by what scientists are said to have told journalists, expects some dramatic human dividends in future." In reality, Burnet insisted, the contribution of laboratory science to medicine had very nearly come to an end. "However fascinating it may be as a scholarly achievement," he wrote, "there is virtually nothing that has come from molecular biology that can be of any value to human living in the conventional sense of what is good. and quite tremendous possibilities of evil, again in the conventional sense."

Those comments provoked dismay when they were first written. Today, they arouse little more than mild amusement. Their rightful place is alongside such historic gems from the Nobel-prizewinning class at Robert Millikan's 1923 prediction that "There is no likelihood man can ever tap the power of the atom. The glib supposition of utilising atomic energy when our coal has run out is a completely unscientific Utopian dream, a childish bug-aboo, " or Ernest Ruther- ford's assurance, 10 years later, that "The energy produced by the breaking down of the atom is a very poor kind of thing. Anyone who looks for a source of power in the transformation of the atom is talking moonshine."

Which brings us to Roy Fuchs and his Monsanto colleagues in St. Louis, Missouri. It is a measure of the transformation wrought by molecular biology throughout the biosciences over the 50 years since Beadle and Tatum's work on fungal genetics, and in the biotechnologies in the 20 years since Macfarlane Burnet's dismal sermon, that many problems of second-order difficulty are now being solved. One of those is the production of plants with builtin resistance to fungal pathogens. Whereas several groups have introduced and expressed heterologous genes to make plants tolerant of viruses, herbicides, and certain groups of insects, engineering resistance against fungi has proved to be a far less straightforward undertaking. A report by Michael Fiske, Karen Tobey-Fincher, and Roy Fuchs in the current Joumal of General Microbiology $(136: 2377,1990)$ indicates that the conundrum is well on the way to being solved.

Although fungi are by far the most important plant pathogens, progress in fashioning resistance has been bedevilled by ignorance of natural (or indeed unnatural) defences, whose genes might be cloned and spliced into otherwise sensitive varieties. Even today, we know of no specific proteins comparable for biological control of insect pests. An alternative approach, which the Monsanto work suggests is going to be a winning gambit, is to harness genes encoding for hydrolytic enzymes that are capable of breaking down key structural components of the fungal cell wall such as chitin and 1,3-B-glucans.

Peas and certain other plants have been shown to produce both chitinase and 1,3-B-glucanase in response to fungi such as Fusarium solani, and it is assumed that induction of these enzymes plays a natural role in disease protection. Fuchs and his co-workers decided to clone genes expressing 1,3-8glucanase activity from a bacterium. They constructed a cosmid library of Bacillus circulans WL 12 DNA, screened it in Escherichia coli, and identified two clones containing genes encoding two different 1,3-B-glucanases. Purified from their respective strains, the enzymes were shown to have strong catalytic activity towards yeast cell wall preparations.

The Monsanto workers are now poised to insert their two new genes, logether with a Serratia marcescens chitinase gene they have already cloned, into plants as a means of conferring resistance to fungal infection. Such an achievement, if it comes before the end of 1991, will coincide most fittingly with the anniversary of Beadle and Tatum's introduction of fungi into genetics research. It would also provide further proof that even the greatest scientists can go wildly awry in assessing the practical repercussions of their craft. 